\title{
Emergency Contraception: a survey of Hospital Emergency Departments Staffs
}

\author{
Marco Bo*, Ivo Casagranda**, Mario Galzerano***, Lorena Charrier***, Maria Michela Gianino*** \\ * Legal Medicine Unit, University of Turin, Italy \\ ** Emergency Department, S.S. Antonio e Biagio e Cesare Arrigo Hospital Trust, Alessandria, Italy \\ *** Department Public Health, University of Turin, Italy
}

\begin{abstract}
The World Health Organization defines emergency contraception $(E C)$ as a means to prevent unwanted pregnancy. In countries where $E C$ is dispensed behind the counter, emergency departments are a preferred point of care for its prescription and dispensing. In light of this situation and as no studies on emergency contraception in emergency departments in Italy have been conducted to date, this study was designed with a view to analyze the responses of emergency room physicians in relation to their prescribing habits and knowledge about the drug and in relation to frequency and profile of women arriving for care at hospital emergency departments in Piedmont and requesting prescription for the morning-after pill. This cross-sectional survey involved 29 hospital emergency departments in Piedmont where no gynecologists are on active duty. The survey
\end{abstract}

\section{Introduction}

Emergency contraception (EC) refers to the use of drugs or intrauterine devices (IUD) to prevent unwanted pregnancy after an unprotected sexual intercourse.

The World Health Organization (WHO) defines EC as a means to prevent an unwanted pregnancy which constitutes an important risk factor for a woman's health.

Studies in Europe and the United States investigating the characteristics of requests for $\mathrm{EC}$ prescription have found that the majority are made by young women ( $<30$ years of age), single or nulliparous, with a middle-to-high education level (1-6). Requests are most frequent during the summer months (June to September), around holidays (e.g., New Year's) and the weekend (Saturday to Monday) $(3,4,7)$ and within the first 24 hours after sexual intercourse $(3,5,7)$.

In light of these data, in countries where EC is dispensed behind the counter, emergency departments are a preferred point of care for its prescription and administration: emergency department services are operated around the clock, hold a supply of the drug and, in some instances, may be an ideal setting for educating women about safe sex practices and how to prevent sexually transmitted infections (STIs) (8). For these reasons, studies have investigated the propensity of emergency department medical staff to dispense EC. In 1995 Gbolade (9) administered a questionnaire to the heads of ED in the United Kingdom to find out what they felt about prescribing EC. Analysis of the responses revealed that only 57\% prescribed EC, despite their knowing that the pill had to be taken within 72 hours after sexual intercourse, since they didn't believe it an appropriate part of emergency room services and didn't consider unprotected sexual intercourse an unexpected urgent accident. If the emergency physician on duty was unwilling to administer the pill, the women were referred to their general practitioner, a family-planning center or in some cases to a gyne- instrument was a 24-item questionnaire. Analysis of responses revealed that in the physicians' opinion the vast majority of requests came from Italian nationals (97\%) ranging in age from 18 to 30 years $(76 \%)$, single and not cohabiting with a partner (60\%), and nulliparous (64.0\%). Women mostly request EC for first-time and the most common reasons were condom breakage or slippage. Just over half the physicians (52\%) stated that emergency contraception prescription was not an appropriate part of care provided at an emergency department and $72 \%$ stated they felt uneasy about prescribing emergency contraception. The survey also revealed gaps in physician knowledge about the pharmacokinetic and pharmacodynamic properties of emergency contraception pills.

cologist on duty, especially during the weekend. Drawing from these responses, the study concluded that refusal to offer EC was linked to several factors, including the physician's personal ethos and knowledge about the drug.

A similar study conducted in Oregon in 2003 (10), which also employed a questionnaire, found that physician attitudes differed depending on whether the woman had been sexually assaulted or had consented to unprotected intercourse: $46 \%$ of emergency physicians did not provide EC to women requesting it, if they had consented to unprotected intercourse; the women were referred to another medical facility where they could obtain EC.

The same questionnaire was later administered to a sample of medical staff in New Mexico (11): in 21\% of cases, the request was motivated by consensual unprotected intercourse and in $52 \%$ by an episode of sexual assault; in 13\% of cases, the women were referred to an external health care provider, and in $15 \%$ they received neither a prescription nor a referral to another medical facility, despite the medical staff's knowing the time limit for effective EC. A 2005 national telephone survey in which anonymous requests for EC were made to 600 emergency departments in the U.S. (12) revealed that EC was never offered at $42 \%$ of non-Roman Catholic hospitals or at $55 \%$ of Roman Catholic hospitals; in $45 \%$ of the latter, EC was offered only to sexual assault victims and after the woman had undergone specific procedures - pregnancy testing and police reports - but still at the discretion of the physician on duty. In instances of refusal to provide EC, the physician referred the woman to an external health provider in only $50 \%$ of cases, without being sure in $80 \%$ of such cases whether the facility would in fact offer EC. An additional finding was that emergency department medical staff was poorly informed about EC.

While there are data about EC prescription practices in European countries and the U.S., no data are available for Italy where EC 
is dispensed behind the counter. To fill this gap, we conducted this study in emergency departments in Piedmont. The study was conducted within the framework of targeted research and was funded by the Piedmont Region.

The aims of the study were to analyze the responses of emergency department medical staff in relation to: 1) EC prescription, specifically with regard to behavior toward the prescription requests and to the prescriber's degree of knowledge about the modes of prescription and administration of the drug 2) the frequency and profile of women arriving for care at emergency departments and requesting prescription of the morning-after pill.

Unlike many U.S. studies investigating differences in physician behavior according to whether they work in a Roman Catholic hospital or a non-Roman Catholic hospital, our study did not address this issue as no church-run hospitals are operated in Piedmont.

\section{Materials and methods}

With this study we used a cross-sectional survey involving 29 emergency departments of hospitals in Piedmont where no gynecologist is on duty. The study period ran the full 2009 calendar year. The survey was conducted using a 24-item questionnaire subdivided into eight areas (Table 1-2). Fourteen items were drawn from international sources and published evidence-based medicine data. Table 3 lists the bibliographic references for each of these items. The remaining 10 items were designed to gain a broader view of the characteristics of women requesting EC prescriptions, the temporal distribution of requests and medical staff knowledge about EC and prescribing behaviors. The questionnaire was administered to emergency department medical staff in participating Piedmont hospitals and took about 30 minutes to complete.

The emergency department medical staff was composed of emergency physicians. This choice was operated to avoid bias linked to specialist knowledge which could have generated an insight bias For this reason, the ED of the obstetrics and gynecologic hospital (Regina Margherita-Sant'Anna Hospital), the trauma center (Hospitals CTO-Maria Adelaide) and the ophthalmic hospital (Sperino Hospital) were excluded from the study.

\section{Statistical analysis}

Descriptive statistical analysis was carried out to calculate the mean and frequency distribution of data. Pearson's Chi-squared test was applied to responses to the items investigating the characteristics of the women requesting $\mathrm{EC}$. This was done to determine whether there was a relationship between the following variables: age and nationality; age and main reason for requesting EC; civil status and main reason for requesting EC.

The same test was performed to reveal a possible influence of emergency department level (I or II) on: peak time of year and peak day during the week for EC requests; civil status of the women requesting EC; history of previous voluntary abortions; frequency of EC use and number of requests made.

With regard to questions about the pharmacokinetic and pharmacodynamic knowledge, physicians' responses were dichotomized into correct and incorrect answer. Univariate analysis were conducted to assess whether sex, age and ED level were associated with the correct answer using the Chi-square test (for sex and ED level) and t-student test for age. In the case where there was a univariate association, this one was examined in multivariate analysis (logistic regression) in which the dependent variable was the correctness of the response and the independent variables were age, sex and ED level. The data were processed using SPSS vers. 16 software for Windows.

\section{Results}

The data were collected from questionnaire responses by 75 emergency physicians (Table 1). Response data are tabulated in Table 2. Analysis of the responses revealed that $68 \%$ of physicians had received from 1 to 20 requests and $24.0 \%$ had received 21-40 requests. The weighted average number of requests in 2009 was an estimated 1250 . In physicians' opinion, requests were most often made by Italian nationals (97\%) between 18 and 30 years of age (76\%) followed by those aged between 14 and 17 years (18.7\%). Most of these women were described as single, not cohabiting with a partner (60.0\%) and nulliparous (64\%). In most instances, first-time requests for EC (57.3\%) because of "Condom breakage, slippage or incorrect use" (50\%) or "Unprotected sexual intercourse" (42\%) were reported. According to ED staff, in $66.0 \%$ of cases requests came from women who had been refused a prescription by another health care provider, chiefly physicians in out of hours service (48\%). While non-specific seasonality for requests could be determined, peak times around the weekend (73.3\%) were reported. Just over half (52\%) of medical staff considered prescribing the morning-after pill as an inappropriate part of emergency department services. This attitude was widely held among physicians working in level I and level II emergency departments, irrespective of where the hospital was located in the region.

Many physicians felt at odds with providing EC: $72 \%$ stated that they felt "Very uncomfortable, slightly uncomfortable or fairly comfortable" about writing out a prescription. Nonetheless, $70.7 \%$ said they prescribed EC and gave information about contraception methods. Some 57.3\% stated that when asked, a physician should always prescribe EC, whereas $25.3 \%$ believed that a physician could affirm the right of conscientious objection on the grounds of the Deontological Code, and 13.3\% in recognition of the provisions of Law 194/78 regulating legal abortion. According to responses to items investigating the prescriber's knowledge about the pharmacokinetics of EC, $62.7 \%$ stated that the pill had to be taken with 72 hours after unprotected intercourse, $37.3 \%$ gave no time limit, and $4 \%$ stated that the pill could be taken within 120 hours after unprotected intercourse. Only 17.3\% correctly knew the time window within which the drug needs to be taken in order to be most effective (12-24 hours after unprotected intercourse, as reported in the literature) (13).

The survey also revealed the prescribers' patchy knowledge about the drug's pharmacodynamics: $96 \%$ knew that the pill does not usually cause significant side effects but may cause nausea, vomiting and headache; $80 \%$ were aware that diagnostic tests before prescribing it are not required; only $52 \%$ correctly remembered the mode of assumption; $11 \%$ believed that EC use can lead to an increase in risky sexual behavior and STIs; $20.6 \%$ stated that it can result in giving up the use of regular contraception.

One important aspect concerned the responses investigating knowledge about the pill's mechanism of action: $70.7 \%$ believed that it has a complex mechanism of action that involves inhibition of ovulation and fecundation, alteration of tubal ciliar motility and sperm motility, and inhibition of embryo implantation, whereas $17.3 \%$ thought it inhibited ovulation, as occurs with other contraceptives.

Statistical analysis revealed a statistically significant relationship between the woman's age and nationality $(\mathrm{p}=0.0001)$ and between

\section{Table 1.}

Profile of emergency department physicians (AREA 1):

\begin{tabular}{|l|l|l|}
\hline Sex & $\begin{array}{l}\text { Male (\%) } \\
56.8\end{array}$ & $\begin{array}{l}\text { Female (\%) } \\
43.2\end{array}$ \\
\hline $\begin{array}{l}\text { Mean age } \pm \text { SD } \\
\text { (yrs) }\end{array}$ & $44.2 \pm 7.4$ [range, 32-59] \\
\hline $\begin{array}{l}\text { Levels of emer- } \\
\text { gency department* }\end{array}$ & Level I (45.7\%) & Level II (54.3\%) \\
\hline $\begin{array}{l}\text { Location of emer- } \\
\text { gency department }\end{array}$ & $\begin{array}{l}\text { In a hospital in a } \\
\text { provincial or regional } \\
\text { seat (49.3\%) }\end{array}$ & $\begin{array}{l}\text { In a hospital in } \\
\text { another town/city } \\
(50.7 \%)\end{array}$ \\
\hline
\end{tabular}

Level II is more advanced than Level I 
Table 2

Frequency distribution of physicians' responses

\begin{tabular}{|c|c|}
\hline $\begin{array}{l}\text { AREA 2: Number and frequency distribution of EC } \\
\text { prescription requests }\end{array}$ & $\% *$ \\
\hline \multicolumn{2}{|l|}{$\begin{array}{l}\text { I. How many requests for the morning-after pill did you } \\
\text { receive in the past year? }\end{array}$} \\
\hline 0 & 1,3 \\
\hline $\mathrm{I}-20$ & 68 \\
\hline $21-40$ & 24 \\
\hline $4 I-80$ & 5,3 \\
\hline $80-150$ & 0 \\
\hline$>150$ & 0 \\
\hline Unknown & $\mathrm{I}, 4$ \\
\hline \multicolumn{2}{|l|}{$\begin{array}{l}\text { 2. In which period of the year were requests most fre- } \\
\text { quent? }\end{array}$} \\
\hline Winter & 6,7 \\
\hline Spring & 13,3 \\
\hline Summer & 8 \\
\hline Autumn & 2,7 \\
\hline None of the above & 69,3 \\
\hline \multicolumn{2}{|l|}{ 3. On which days were requests most frequent? } \\
\hline Monday & 2,7 \\
\hline Tuesday through Friday & 2,7 \\
\hline Weekend & 73,3 \\
\hline Monday through Friday & 0 \\
\hline Tuesday through Sunday & 5,3 \\
\hline Weekend through Monday & 1,3 \\
\hline None of the above & 4 \\
\hline
\end{tabular}

AREA 3: Demographics of women requesting EC prescription

\section{Woman's age (years)}

\begin{tabular}{|l|l|}
\hline $14-17$ & 18,7 \\
\hline $18-30$ & 76 \\
\hline $3 I-40$ & 2,7 \\
\hline $4 I-50$ & \\
\hline Unknown & 1,3 \\
\hline 5.Woman's na tionality & \\
\hline Italian & 97,2 \\
\hline Foreign & 2,8 \\
\hline
\end{tabular}

AREA 4: Characteristics of management of pregnancy of women requesting $\mathrm{EC}$ prescription

\section{Civil status}

Single, not cohabiting with partner 60

Cohabiting with partner

Married

Unknown

\begin{tabular}{|l|l|}
\hline 7. Parousness & 64 \\
\hline Nulliparous & 0 \\
\hline Parous & 30,7 \\
\hline Unknown & 4 \\
\hline 8. History of previous elective abortion & 30,7 \\
\hline Yes & 60 \\
\hline No & \multicolumn{2}{|l|}{} \\
\hline Unknown & 57,3 \\
\hline 9. EC prescription requested by a woman who: & 22,7 \\
\hline Requested EC for the first time & 20 \\
\hline Requested EC in the past & 50,3 \\
\hline Unknown & 6,7 \\
\hline I0.The main reason for requesting EC prescription was: \\
\hline Condom breakage, slippage or incorrect use & 42 \\
\hline $\begin{array}{l}\text { Forgot to use another method of contraception or the } \\
\text { method failed }\end{array}$ & I \\
\hline Unprotected sexual intercourse & \\
\hline Unknown &
\end{tabular}

AREA 5: Prescriber's knowledge about the EC pill's pharmacokinetics

I I. In which of the following circumstances do you believe providing the morning-after pill is indicated:

\begin{tabular}{|l|l|}
\hline $\begin{array}{l}\text { Unprotected sexual intercourse in the I20 hours preceding } \\
\text { the request }\end{array}$ & 6,7 \\
\hline Unprotected sexual intercourse in fertile period & 9,3 \\
\hline $\begin{array}{l}\text { Unprotected sexual intercourse with subsequent risk of } \\
\text { pregnancy }\end{array}$ & 20 \\
\hline Sexual assault & 1,3 \\
\hline All of the above & 56 \\
\hline None of the above & 6,7 \\
\hline
\end{tabular}

12. Within how many hours after intercourse should the morning-after pill be prescribed:

\begin{tabular}{|c|c|}
\hline $12-24$ & 9,3 \\
\hline 48 & 24 \\
\hline 72 & 62,7 \\
\hline 120 & 4 \\
\hline Don't know & 0 \\
\hline
\end{tabular}

13. Within how many hours after sexual intercourse does the morning-after pill lose the most of its effectiveness:

\begin{tabular}{|l|l|}
\hline $12-24$ & 17,3 \\
\hline 48 & 21,3 \\
\hline 72 & 52 \\
\hline 120 & 6,7 \\
\hline Don't know & 2,7 \\
\hline
\end{tabular}


Table 2

\begin{tabular}{|c|c|}
\hline \multicolumn{2}{|l|}{$\begin{array}{l}\text { 14. What are the modes of assumption of the morning- } \\
\text { after pill: }\end{array}$} \\
\hline $\begin{array}{l}\text { The first pill must be taken at prescription and the second } \\
12 \text { hours later }\end{array}$ & 13, \\
\hline Both pills should be taken concurrently at prescription & 52 \\
\hline Both of the above & 33 \\
\hline Don't know & 1,3 \\
\hline
\end{tabular}

15. Does the morning-after pill cause major side effects:

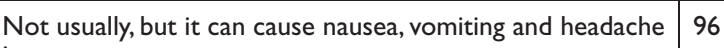
in some cases

\begin{tabular}{|l|l}
\hline Yes, severe metrorrhagia & 2,7 \\
\hline Yes, fetal malformations if contraception ineffective & 0 \\
\hline Yes, other effects & 1,3
\end{tabular}

16. Diagnostic determinations must be performed before prescribing the pill:

\begin{tabular}{|l|l|}
\hline No & 80 \\
\hline Yes, blood coagulation test & 2,7 \\
\hline Yes, pregnancy test & 16 \\
\hline Yes, for other reasons & \\
\hline
\end{tabular}

17. What is the mechanism of action of the morning-after pill:

Inhibits ovulation, like other oral contraceptives

Through a complex mechanism of action involving inhibition of ovulation and fecundation, alteration of tubal ciliar motility and sperm motility, inhibition of implantation of embryo

Through an abortive mechanism like that of RU486

18. Use of the morning-after pill can lead to:

\begin{tabular}{|l|l|}
\hline An increase in risky sexual behavior and STIs & II \\
\hline An increased risk of no longer using regular contraception & 20,6 \\
\hline A decrease in unwanted pregnancies & 25,8 \\
\hline A decrease in elective abortions & 27,1 \\
\hline Greater self-determination for women & 7,7 \\
\hline None of the above & 7,7 \\
\hline
\end{tabular}

\section{AREA 7: Prescriber's behavior/attitudes}

19. Do you feel that dispensing EC is appropriate for an emergency department:

\begin{tabular}{|l|l|}
\hline Yes & 52 \\
\hline No & 48 \\
\hline
\end{tabular}

20. How comfortable do you feel about dispensing the morning-after pill:

\begin{tabular}{|l|l|}
\hline Very uncomfortable & $2 \mathrm{I}, 3$ \\
\hline Slightly uncomfortable & 24 \\
\hline Fairly comfortable & 26,7 \\
\hline Very comfortable & 5,3 \\
\hline Absolutely comfortable & 21,3 \\
\hline
\end{tabular}

\begin{tabular}{|c|c|}
\hline \multicolumn{2}{|l|}{$\begin{array}{l}\text { 21.When asked to give the morning-after pill, do you } \\
\text { generally: }\end{array}$} \\
\hline $\begin{array}{l}\text { Prescribe it and give information about regular contra- } \\
\text { ception }\end{array}$ & 70,7 \\
\hline $\begin{array}{l}\text { Prescribe it but do not give information about regular } \\
\text { contraception }\end{array}$ & 18,7 \\
\hline $\begin{array}{l}\text { Refuse to give it and refer the woman to a gynecologist } \\
\text { instead }\end{array}$ & 4 \\
\hline $\begin{array}{l}\text { Refuse to give it and inform the woman that it would give } \\
\text { conscientious objection }\end{array}$ & 2,7 \\
\hline
\end{tabular}

\section{AREA 8: Role of the prescriber in the emergency depart-} ment

22. When asked to give the morning-after pill:

\begin{tabular}{l|c|}
\hline It should always be provided & 57,3 \\
\hline $\begin{array}{l}\text { It may be offered in some circumstances or give conscien- } \\
\text { tious objection on the basis of the deontological code }\end{array}$ & 25,3 \\
\hline $\begin{array}{l}\text { It may be offered in some circumstances or give conscien- } \\
\text { tious objection on the basis of Law I94/78 }\end{array}$ & 13,3 \\
\hline
\end{tabular}

23. Has it ever happened that one or more women arrived for care at the emergency department where you work and asked for the morning-after pill because they had been refused at another medical facility:

\begin{tabular}{|l|l|}
\hline Yes & 65,8 \\
\hline No & 34,2 \\
\hline
\end{tabular}

24. If yes, what type of health care provider did they usually seek before coming to your department:

\begin{tabular}{|l|l|}
\hline Another emergency department & 23,2 \\
\hline A physician on out of hours service & 47,8 \\
\hline A family-planning service & 4,3 \\
\hline A general practitioner & 11,7 \\
\hline Unknown & 13 \\
\hline
\end{tabular}

*the\% of respondents take into account the missing

age and main reason for requesting the $\mathrm{EC}$ pill $(\mathrm{p}=0.0001)$ and between civil status and reason for requesting the EC pill $(\mathrm{p}=0.0001)$. Sex, age and emergency department level did not affect the pharmacodynamics knowledge of the physicians interviewed (Table 4).Sex was associated with correct knowledge of the time within which EC can be administered in univariate analysis but not in multivariate analysis. A statistically significant effect was noted between the ED's level and the knowledge of the time window within which the drug needs to be taken in order to be most effective (Table 4).

A statistically significant effect $(p=0.003)$ was noted between emergency department level and peak months but not peak days for EC requests ( $\mathrm{p}=0.56)$; a statistically significant effect was also seen between emergency department level and reported woman's civil status $(\mathrm{p}=0.001)$, history of previous voluntary abortion $(\mathrm{p}=0.004)$ and request for the EC pill ( $\mathrm{p}=0.001)$, whereas no statistically significant effect was noted for the number of requests made ( $\mathrm{p}=0.93$ ).

\section{Discussion}

The strengths of this survey are that it was conducted from the perspective of emergency medical staff $(10,12)$ rather than that of women arriving for care at the casualty department (1-3); involved emergency departments in secular hospitals; analyzed re- 
Table 3.

Bibliographic references for questionnaire items.

\begin{tabular}{|l|l|}
\hline Study & $\begin{array}{l}\text { Question- } \\
\text { naire item }\end{array}$ \\
\hline $\begin{array}{l}\text { Gbolade BA, Elstein M, Yates D. UK accident and } \\
\text { emergency departments and emergency contracep- } \\
\text { tion: what do they think and do? J Accid Emerg Med. } \\
\text { I999 Jan; I6(I):35-8. }\end{array}$ & $\mathrm{I}, 19,21$ \\
\hline $\begin{array}{l}\text { Golden NH, Seigel WM, Fisher M, Schneider M, } \\
\text { Quijano E, Suss A, Bergeson R, Seitz M, Saun- } \\
\text { ders D. Emergency contraception: pediatricians } \\
\text { knowledge, attitudes, and opinions. Pediatrics. 200 I } \\
\text { Feb; I07(2):287-92. }\end{array}$ & $\begin{array}{l}\mathrm{I}, 10,12, \\
13,15,16,\end{array}$ \\
\hline $\begin{array}{l}\text { Millar JR, Leach DS, Maclean AV, Kovacs GT. } \\
\text { The use of emergency contraception in Australa- } \\
\text { sian emergency departments. Emerg Med. 200 I } \\
\text { Sep; I3(3):3 I4-8. }\end{array}$ & $12,14,21$ \\
\hline $\begin{array}{l}\text { Bastianelli C, Farris M, Benagiano G. Reasons for } \\
\text { requesting emergency contraception: } \text { a survey of 506 } \\
\text { Italian women. Eur J Contracept Reprod Health } \\
\text { Care. 2005 Sep; I0(3): I57-63. }\end{array}$ & $9,10,18,23$, \\
\hline
\end{tabular}

quests for EC from women of reproductive age (14-50 years old) rather than being limited to either the over-18 years of age population, as in studies by Kosunen (2), Aneblom (3), and Olszewski (7), or adolescents $(<18$ years of age $)(6)$.

Analysis of survey responses show that the largest age group comprised women aged $18-30$ years old $(76 \%)$, similar to findings by Kosunen (70.8\%) (2), Bastianelli (87.1\%) (1), and Aneblom (88.9\%) (3), followed by adolescent girls (14-17 years old) (18.7\%), unlike Bastianelli (1) who reported the over-30 years of age group as second largest group (8.9\%). In line with Kosunen's observations (50\%) (2), in physicians'opinion most women were single and not cohabiting with a partner $(60.0 \%)$, but unlike those of Aneblom (3), nulliparous (64.0\%). The vast majority of women were described as Italian nationals (97.2\%).

Except for the frequency of requests from adolescents, our survey results are substantially similar to those reported by other studies. Our results differ in that they reflect the perceptions of medical staff with regard to EC prescription, and as such, might have been influenced by an insight bias. In this connection, it would be interesting to compare our findings with survey samples of women residing in the same area. Another aspect to emerge from our study was the overwhelming preponderance of Italian nationals, from which it could be inferred that non-Italian nationals are either unaware of the morning-after pill or encounter barriers to access to EC. This question merits further study.

Interviewed physicians stated that most cases of women arriving for care were first-time requests for EC, as previously reported by Checa (93\%) (4) and Bastianelli (93\%) (1), and motivated by condom breakage or slippage, as found by Vergara Cano (91\%) (5) and Bastianelli (64\%) (1).

Unlike the data Checa (4) reported in their 9-year epidemiological study describing a net seasonal peak of EC requests during the summer months, we observed no seasonal trends; instead, weekend peaks were noted, in line with observations by Checa (4) and other reports $(3,4,7)$. In contrast, emergency department level appeared to influence the seasonal but not the weekly distribution of request frequency.

In general, our results show that neither prescriber sex nor age had an effect on knowledge of the EC pill's pharmacokinetics or pharmacodynamics, whereas emergency department level did. Specifically, physicians working in a level I emergency department were more knowledgeable about the reduction time of the EC's effectiveness, which did not appear to be correlated to familiarity with prescribing it, given the lack of a statistically signifi- cant difference in the frequency of requests between level I and level II emergency departments.

Regarding knowledge about the pill's pharmacokinetics, most emergency physicians responded correctly to the items investigating reasons and time window for prescription; most did not limit its prescription to particular circumstances (e.g., sexual assault, risk of current pregnancy); but, again, most stated that the pill had to be given within the first 72 hours after intercourse to be effective. Indeed, the question of its effective time limit (72 vs. 120 hours postcoitus) remains controversial. EC products commercially available in Italy carry the indication for use within 72 hours after unprotected intercourse, but the WHO recommends prescribing EC within 120 hours postcoitus (14). According to a recent systematic literature review (13), no significant reduction in effectiveness was observed when levonorgestrel was administered within 72 versus 120 hours after unprotected intercourse. That is discussed as the option of prescribing ulipristal acetate for EC requested more than 72 hours after intercourse (15-17). As regards prescriber's knowledge about the pill's pharmacodynamics, the responses often differed from those expected. Many physicians stated that the first pill should be taken at prescription and the second within 12 hours, whereas the WHO recommends taking both pills contemporaneously. Currently, there is no scientific evidence that concomitant administration can significantly diminish the pill's effectiveness; instead, the underlying reason is that in this way the risk of forgetting to take the second pill is averted and consequently the potential failure to reach the recommended dose $(13,14)$.

While many physicians stated that EC use could lead to an increase in risky sexual behavior and STIs, this belief has never been corroborated by published data.

Also intriguing was the widely held notion that EC pills have a complex mechanism of action rather than acting through simple inhibition of ovulation. Research conducted to date has demostrated that the pills inhibit ovulation, but the role of the other mechanisms of action remain controversial (18-20) which is perhaps why the responses given in our study differed from those expected. In line with previously published data on the frequency distribution of requests for $\mathrm{EC}$, our survey results show that requests were most frequent at the weekend, when continuity of care is provided only by physicians on out of hours service and by emergency departments. Unlike other reports (1), our survey found that the ED was the first point of care in only $34.2 \%$ of cases. A partial explanation for this difference could be that women preferred seeking care first from a physician on out of hours service (47.8\%) and, if refused, by the health provider subsequently turned to a emergency department. Our data indicate that the majority of emergency physicians (70.7\%) are willing to provide EC, which corresponds to the percentage of women who reported having been refused the morning-after pill at another ED. This finding should be viewed with caution, however; many of the questionnaire respondents are probably aware of this problem and this might have been a cause of overestimation. Also, barriers to access to EC could have been caused by the limits placed on care provided through weekend/holiday work shifts during peak periods and by the $30 \%$ of physicians who refuse to offer EC. Furthermore, although the ED appears to be a preferred point of care for seeking EC, many emergency physicians felt uneasy about prescribing EC and did not consider it an appropriate part of emergency department services. A variety of reasons may underlie this uneasiness with EC prescription: dispensing EC may not be seen as a real emergency or urgent medical need requiring the services of an emergency department; EC prescription may be viewed as a matter for specialists; offering EC may conflict with personal ethos if perceived as a form of abortion. Indeed, all the physicians who give conscientious objection to EC prescription grounded their claim on the provisions of Law 194/78 regulating legal voluntary abortion. They also stated that the pill has a mechanism of action that induces abortion or works through a complex mechanism of action that inhibits implantation of the embryo in the uterus, which some consider to be morally similar to abortion. 
Table 4.

Results of univariate and multivariate analysis on the physicians' responses with regard to knowledge of pharmacokinetics and pharmacodynamics of $\mathrm{E}$

\begin{tabular}{|c|c|c|c|c|c|c|}
\hline & \multicolumn{2}{|c|}{ Gender (F vs M) } & \multicolumn{2}{|c|}{ DEA_level (II vs I) } & \multicolumn{2}{|c|}{ Age } \\
\hline & Univariate an. & Multivar. an & Univariate an. & Multivar. an & Univariate an. & Multivar. an \\
\hline & $\begin{array}{l}\text { OR }(\mathrm{Cl} 95 \%) \\
\text { p-value }\end{array}$ & $\begin{array}{l}\text { OR }(\mathrm{Cl} \\
95 \%) \\
\text { P-value }\end{array}$ & $\begin{array}{l}\text { OR }(\mathrm{Cl} 95 \%) \\
\text { p-value }\end{array}$ & $\begin{array}{l}\text { OR }(\mathrm{Cl} \\
95 \%) \\
\text { P-value }\end{array}$ & p-value & p-value \\
\hline \multicolumn{7}{|c|}{ Prescriber's knowledge about the EC pill's pharmacokinetics } \\
\hline $\begin{array}{l}\text { Item } \mathrm{n} \text {. II - Correct answer: Unprotected sexual } \\
\text { intercourse in the I } 20 \text { hours preceding the } \\
\text { request }\end{array}$ & $\begin{array}{l}2.07(0.32 \\
13.5) \\
0.43\end{array}$ & & $\begin{array}{l}1.29(0.20 \\
8.3) \\
0.79\end{array}$ & & 0.22 & \\
\hline Item n. 12 - Correct answer: $72^{*}$ & $\begin{array}{l}2.73(0.97 \\
7.7) \\
0.047\end{array}$ & $\begin{array}{l}2.61(0.88 \\
7.7) \\
0.08\end{array}$ & $\begin{array}{l}0.63(0.23 \\
1.7) \\
0.35\end{array}$ & & 0.86 & \\
\hline Item n. 13 - Correct answer: 12-24 & $\begin{array}{l}0.79(0.23 \\
2.7) \\
0.70\end{array}$ & & $\begin{array}{l}0.05(0.005 \\
0.5) \\
<0.01\end{array}$ & $<\left.0.0\right|^{\wedge}$ & 0.40 & \\
\hline \multicolumn{7}{|c|}{ Prescriber's knowledge about the EC pill's pharmacodynamics } \\
\hline $\begin{array}{l}\text { Item n. I4 - Correct answer: Both pills should be } \\
\text { taken concurrently at prescription* }\end{array}$ & $\begin{array}{l}1.29(0.51 \\
3.3) \\
0.59\end{array}$ & & $\begin{array}{l}0.88(0.34 \\
2.3) \\
0.79\end{array}$ & & 0.78 & \\
\hline $\begin{array}{l}\text { Item n. I } 5 \text { - Correct answer: Not usually, but it } \\
\text { can cause nausea, vomiting and headache in some } \\
\text { cases }\end{array}$ & $\begin{array}{l}0.11(0.01 \\
2.4) \\
0.08\end{array}$ & & $\begin{array}{l}0.58(0.05 \\
\quad 6.8) \\
0.66\end{array}$ & & 0.33 & \\
\hline Item n. 16 - Correct answer: No & $\begin{array}{l}1.52(0.45 \\
5.1) \\
0.50\end{array}$ & & $\begin{array}{l}1.29(0.39 \\
4.2) \\
0.67\end{array}$ & & 0.96 & \\
\hline $\begin{array}{l}\text { Item n. I } 7 \text { - Correct answer: Inhibits ovulation, like } \\
\text { other oral contraceptives }\end{array}$ & $\begin{array}{l}1.60(0.47 \\
5.5) \\
0.44\end{array}$ & & $\begin{array}{l}0.86(0.24 \\
3.0) \\
0.82\end{array}$ & & 0.16 & \\
\hline
\end{tabular}

* UNDP, UNFPA, WHO,World Bank Special Programme of Research, Development and Research Training in Human Reproduction (HRP). Fact sheet on the safety of levonorgestrel-alone emergency contraceptive pills (LNG ECPs)

$\wedge \mathrm{ED}$ of level II predicts perfect failure (no correct answers)

\section{References}

1. Bastianelli C, Farris M, Benagiano G. Reasons for requesting emergency contraception: a survey of 506 Italian women. Eur J Contracept Reprod Health Care. 2005 Sep;10(3):157-63.

2. Kosunen E, Sihvo S, Hemminki E. Knowledge and use of hormonal emergency contraception in Finland. Contraception. 1997 Mar;55(3):153-7.

3. Aneblom $G$, Larsson M, von Essen L, Tydén T. Women's voices about emergency contraceptive pills "over-the-counter": a Swedish perspective. Contraception. 2002 Nov;66(5):339-43

4. Checa MA, Pascual J, Robles A, Carreras R. Trends in the use of emergency contraception: an epidemiological study in Barcelona, Spain (19942002). Contraception. 2004 Sep;70(3):199-201

5. Vergara Cano JC, López-Guerrero Almansa A, López López F. Anticoncepción de emergencia: perfil de la usuaria en servicios de urgencias de atención primaria. Aten Primaria. 2004 Oct 15;34(6):279-82

6. Falah-Hassani K, Kosunen E, Shiri R, Rimpelä A. Emergency contraception among Finnish adolescents: awareness, use and the effect of nonprescription status. BMC Public Health. 2007 Aug 9;7:201.

7. Olszewski J, Olszewska H, Abacjew A, Chmylko L, GaworskaKrzeminska A. The use of emergency contraception in young Polish women. Acta Obstet Gynecol Scand. 2007;86(7):861-9.

8. Douglass M. Emergency contraception in the ED. J Emerg Nurs. 2007 Apr;33(2):140-2.

9. Gbolade BA, Elstein M, Yates D. UK accident and emergency departments and emergency contraception: what do they think and do? J Accid Emerg Med. 1999 Jan;16(1):35-8

10. Rosenberg KD, Demunter JK, Liu J. Emergency contraception in emergency departments in Oregon, 2003. Am J Public Health. 2005 Aug;95(8):1453-7. Epub 2005 Jun 28

11. Espey E, Ogburn T, Leeman L, Buchen E, Angeli E, Qualls C. Compli- ance with mandated emergency contraception in New Mexico emergency departments. J Womens Health (Larchmt). 2009 May;18(5):619-23.

12. Harrison T. Availability of emergency contraception: a survey of hospital emergency department staff. Ann Emerg Med. 2005 Aug;46(2):105-10.

13. Cheng L, Gülmezoglu AM, Piaggio G, Ezcurra E, Van Look PF. Interventions for emergency contraception. Cochrane Database Syst Rev. 2008 Apr 16;(2):CD001324

14. UNDP, UNFPA, WHO, World Bank Special Programme of Research, Development and Research Training in Human Reproduction (HRP). Fact sheet on the safety of levonorgestrel-alone emergency contraceptive pills (LNG ECPS). [last access 30 oct 2010] Downloaded by http:// www.who.int/reproductivehealth/publications/family_planning/ HRP_RHR_10_06/en/

15. Glasier AF, Cameron ST, Fine PM, Logan SJ, Casale W, Van Horn J et al. Ulipristal acetate versus levonorgestrel for emergency contraception: a randomised non-inferiority trial and meta-analysis. Lancet. 2010 Feb 13;375(9714):555-62.

16. Page GH, Verhaeghe V. Ulipristal acetate for emergency contraception? Lancet. 2010 May 8;375(9726):1608

17. Piaggio G, von Hertzen H. Ulipristal acetate for emergency contraception? Lancet. 2010 May 8:375(9726):1607-8

18. Croxatto HB, Devoto L, Durand M, Ezcurra E, Larrea F, Nagle C, et al. Mechanism of action of hormonal preparations used for emergency contraception: a review of the literature. Contraception. 2001 Mar;63(3):111-21

19. Gemzell-Danielsson K, Marions L. Mechanisms of action of mifepristone and levonorgestrel when used for emergency contraception. Hum Reprod Update. 2004 Jul-Aug;10(4):341-8. Epub 2004 Jun 10. Review.

20. Novikova N, Weisberg E, Stanczyk FZ, Croxatto HB, Fraser IS. Effectiveness of levonorgestrel emergency contraception given before or after ovulation--a pilot study. Contraception. 2007 Feb;75(2):112-8. 